\title{
The FCC and Broadcasting License Renewals: Perspectives on WHDH
}

In $W H D H$, Inc., ${ }^{1}$ the Federal Communications Commission ignored traditional considerations and refused to renew a television license despite faultless operation by the broadcaster. ${ }^{2}$ Denounced by industry spokesmen as an unprecedented decision threatening the ownership of three billion dollars worth of stations in the top fifty markets, ${ }^{3}$ the opinion has provoked a controversy which should lead to congressional reconsideration of the proper function of license renewals.

The Federal Radio Act, ${ }^{4}$ the predecessor of the present Communications Act, ${ }^{5}$ was enacted primarily to correct the problem of overcrowded frequencies. ${ }^{b}$ Although the Commission's power is conceded to exceed that of an air waves traffic policeman, ${ }^{7}$ communications regulation has had to proceed virtually unguided by statutory policy. In its

116 F.C.C.2d 1, 15 P \& F Radio REG. 20 411, rehearing denied, 17 F.C.C.2d 856, 16 P \& F Radio REg. 20 185 (1969).

2 The Commission decision [WHDH, Inc.] marks the first time in history that a license has been declared forfeit with no finding of fault; the first time in history that a renewal applicant has been denied by holding its operational record to be irrelevant .... To bring about these results the Commission had to invoke a set of rules which state within their own language that they are not to apply to renewal proceedings. ...

Letter from Harold E. Clancy, President of the Boston-Herald Traveler Corporation (the parent company of WHDH), to stockholders, Feb. 7, 1969, reprinted in petitioner Boston Broadcasters' brief for rehearing at app. A, 1, WHDH, Inc., 17 F.C.C.2d 856, 16 P \& F RADIO REG. 2D 185 (1969).

3 See Three Billion Dollars in Stations Down the Drain?, 76 Broadcastrng 19 (Feb. 3, 1969). Industry reaction in general has not been moderate. Relying on the political jargon of the day, spokesmen have condemned the decision as part of a "diabolical" scheme concocted by a commission bent on destroying "merely for the sake of destroying-after the fashion of the Yippies." Id. See also Lyndon, FCC License Renewals: Rubber Stamp Is Gone, New York Times, April 27, 1969, at 2, col. 6.

4 Act of Feb. 23, 1927, ch. 169, 44 Stat. 1162.

547 U.S.C. §§ $151-609$ (1964).

6 "From July, 1926 to February 23, 1927, when Congress enacted the Radio Act of 1927 . . almost 200 new stations went on the air. These new stations used any frequencies they desired, regardless of the interference caused to others . . . . The result was confusion and chaos. With everyone on the air, nobody could be heard." National Broadcasting Co. v. United States, 319 U.S. 190, 212 (1943). See generally W. Davis, Radro LAw 30-40 (2d ed. 1930).

7 See National Broadcasting Co. v. United States, 319 U.S. 190, 215 (1943). The "mandate to the FCC to assure that broadcasters operate in the public interest is a broad one, a power 'not niggardly but expansive.' " Red Lion Broadcasting Co. v. FCC, 395 U.S. 367, 380 (1969). 
allocation of scarce frequency licenses, the FCC has been governed by the draftsman's talisman, "the public interest, convenience, and necessity." 8

Since the more profitable broadcast outlets have been allocated, ${ }^{9}$ the proceedings for the renewal rather than for the initial grant of a license would seem to provide the logical forum for the Commission to compare the proposals of competing applicants to the communications policies it has carved from the statutory standard. ${ }^{10}$ These renewal proceedings should function, therefore, as a primary means of encouraging broadcaster operation in conformity with the policy objectives of the FCC. The failure of the Commission's renewal procedure to perform this function has been apparent to observers of the FCC.11 The "traditional considerations" of renewal proceedings, by

8 "In radio ... there never has been a statutory policy. The FCC was simply told to go ahead and regulate in "the public interest." "Jaffe, Book Review, 65 YALE L.J. 1068, 1073 (1956). The Supreme Court has said that "this criterion is as concrete as the complicated factors for judgment in such a field of delegated authority permit, it serves as a supple instrument for the exercise of discretion by the expert body which Congress has charged to carry out its legislative policy." FCC v. Pottsville Broadcasting Co., 309 U.S. 134, 138 (1940). For a dissenting view on the usefulness of the standard see H. FrIENDLY, ThE FederAl Administrative Agencies 54-57 (1962).

o See Notice of Proposed Rule Making, P \& F Radio Reg. Current Serv. 51:7, 9 (1969) and H. Levin, Broadcast Regulation aNd JoInt OWNership of Media 186 (1960) [hereinafter cited as LEvIN]. Based on current statistics made available by the FCC, the number of commercial VHF and UHF channels already in operation or presently available in the top 100 markets are:

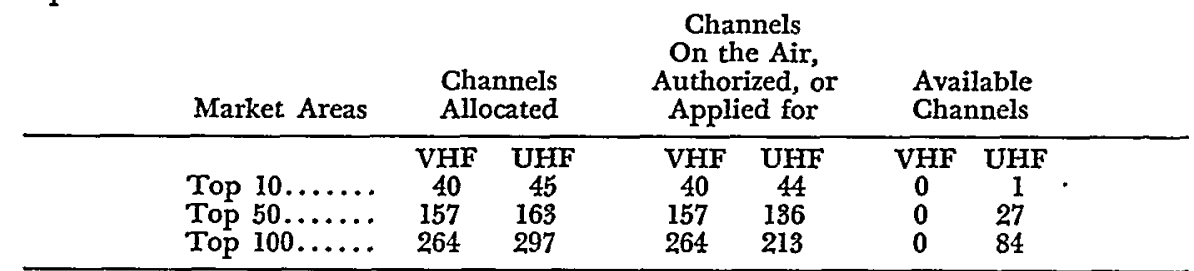

1968 FCG ANN. REP. 132-5.

Television licenses seem to be more profitable and to confer greater political influence than do radio licenses, and it is questionable whether the present controversy would have arisen if the FCC had denied a radio rather than a television license renewal. It might have been reasonable, therefore, to have focused soley on the allocation of television licenses. But since neither the Commission nor the industry has heretofore distinguished between these two types of broadcast licenses, this comment treats them as one, pointing out distinctions where relevant.

10 The FCC can also review transfers of present licenses. See Hearings on S. 1312, The Failing Newspaper Act, Before the Subcomm. on Antitrust and Monopoly of the Senate Comm. on the Judiciary, 90th Cong., Ist Sess., pt. 4, at 2344-5 (1967) [hereinafter cited as Hearings]. 47 U.S.C. $\S 310$ (b) (1964) limits the Commission to a consideration of the merits of the transferee alone. Comparative hearings involving others who might wish to purchase the station are not permitted.

11 See, e.g., Note, Diversification and the Public Interest: Administrative Responsibility of the FCC, 66 YALE L.J. 365, 379 (1957). Several critics of the Commission have dismissed 
shielding licensees from the comparatively better proposals of competing applicants, have caused this failure. ${ }^{12}$ After a brief review of the communications policies endorsed by the Commission, this comment will examine the development, rationale, and weaknesses of the traditional renewal system. It will then propose a method of securing the advantages of comparative hearings without occasioning the widespread losses predicted by the industry in the aftermath of WHDH.

\section{The Policies}

Since this comment proceeds on the premise that a different renewal system is required to implement more effectively the policies of the FGC, some exploration of these policies is essential. The Commission has been concerned with both the structure of the industry and the content of its product. These concerns have not been separated: different structures are presumed to have different effects on programming content. The two principal objectives of the Commission are locally oriented programming and diffusion of control of the mass media.

\section{A. Local Programming}

Two commentators have characterized the statutory guideline on program regulation as one providing

the present communications policies as either worthless or unenforceable and have suggested that the economically efficient use of the spectra should become the primary national communications objective. See generally Coase, The Federal Communications Commission, 2. J. LAw \& ECON. 1 (1959); Levin, Regulatory Efficiency, Reform and the FCC, 50 GEo. L.J. 1 (1961). This objective would be attained through an auctioning of the available spectra. See, e.g., Coase, supra, at 17-35. It is, of course, questionable whether Congress could be persuaded to accept an allocative system premised on private ownership of the spectra. Cf. Levin, Federal Control of Entry in the Broadcast Industry, 5 J. LAw \& EcoN. 49, 62 (1962).

Some commentators have argued that this "mechanical method" of distributing frequencies improperly assumes that the present Commission policies are not useful in making worthwhile discriminations between license applicants. See Grunewald, Should the Comparative Hearing Process Be Retained in Television Licensing?, 13 AM. U.L. REv. 164, 170-1 (1964); Current Problems-Television Service and the FCC, 46 TexAs L. REV. 1100, 1164-5 (1968). Professor Robinson has argued against the auction system because of the effect which it would have on existing uses, the interference it would cause with the technically efficient utilization of the spectra, and for its preference of private over social utility. He has also challenged the assumption that the auction system would lead to greater economy of spectrum use. See Robinson, Radio Spectrum Regulation: The Administrative Process and the Problems of Institutional Reform, 53 MrN. L. REv. 1179 (1969). This comment seeks primarily to demonstrate that an alteration in the traditional renewal procedure is an effective means of implementing policies considered worthwhile.

12 The Supreme Court has noted that "Since the very inception of federal regulation by radio [sic], comparative considerations as to the services to be rendered have governed the application of the standard of "public interest, convenience, or necessity." National Broadcasting Co. v. United States, 319 U.S. 190, 217 (1943). 
a compromise through a contradiction. It charges the Commission to see to it that . . . broadcasting facilities are managed "in the public interest, convenience, or necessity," yet it forbids the FCC to concern itself with the content of ... programs by stigmatizing such sharing of responsibility as interference and censorship. ${ }^{13}$

To avoid the inherent tension between program regulation and the first amendment, the Commission has prescribed "neutral" objectives for programming content. With support from the Supreme Court, the FCC has ruled that to fulfill their obligations under the public interest standard, the licensees should "take the necessary steps to inform themselves of the real needs and interests of the areas they serve, and to provide programming which in fact constitutes a diligent effort ... to provide for those needs and interests." 14

In Henry v. FCC, ${ }^{15}$ the District of Columbia Circuit Court ${ }^{16}$ affirmed the Commission's denial of a license to a sole applicant who was legally, financially, and technically qualified but who had taken no steps to familiarize himself with the needs of the community he wished to serve. Rejecting the applicant's contention that the latter consideration was proscribed both by the statutory prohibition of censorship and the first amendment, the court held that the Commission "may require that an applicant demonstrate an earnest interest in serving a local community by evidencing a familiarity with its particular needs and an effort to meet them."17 The Commission presumes that the more local contacts license applicants have and the more these applicants are integrated into the actual management of the station, the better able the applicant is to discern local needs and interests. ${ }^{18}$

Without prescribing a rigid mold, the Commission has created

13 Friedrich \& Sternberg, Congress and the Control of Radio-Broadcasting (pt. 2), 37 AM. Pol. ScI. REv. 1014, 1024-5 (1943). 47 U.S.C. \$ 326 (1964) forbids censorship by the Commission.

14 Commission Policy on Programming, 25 Fed. Reg. 7291, 7295, 20 P \& F Radio Reg. 1901, 1913 (1960).

15302 F.2d 191 (D.C. Cir.), cert. denied, 371 U.S. 821 (1962).

1647 U.S.C. $\$ 402$ (1964) provides that appeals of FCC decisions denying applications for station licenses, renewals, modifications, or transfers or decisions modifying, revoking, or suspending licenses may be appealed to the District of Columbia Circuit Court, whose judgment is final subject to review by the Supreme Court upon writ of certiorari. Placing the review of an administrative agency's decisions in a single court would seem likely to increase the uniformity of those decisions and the influence which the reviewing court has over the regulatory body. For an example of the court's influence in the renewal area, see text at notes $56-63$ infra.

17302 F.2d at 194. See also National Broadcasting Co. v. United States, 319 U.S. 190, 216 (1943); FCC v. Sanders Bros. Radio Station, 309 U.S. 470 (1940).

18 See note 84 infra. 
fourteen programming categories which are the "major elements usually necessary to meet the public interest, needs and desires of the community in which the station is located." 19 The Commission's request in the renewal application form for information on the time the licensee devotes to each category seems to promote what the FCC terms "balanced programming." The application's particular concern with the time devoted to "public affairs programs" may indicate a preference for such programming. ${ }^{20}$ In addition to orienting its programming to local needs, the broadcaster is also required, under the "fairness doctrine," to afford reasonable opportunity for the presentation of contrasting viewpoints on controversial issues of public importance. ${ }^{21}$ Under a statutory rule of similar intent, the licensee is required to provide equal time to competing candidates for any political office. ${ }^{22}$ Finally, the Commission imposes some additional, specific prohibitions on programming which seem consistent with both the public interest and the first amendment; for example, by statute or regulation, broadcasters are forbidden to broadcast lottery infor-

19 Commission Policy on Programming, 25 Fed. Reg. at 7295, 20 P \& F Radro REg. at 1913 (1960). The categories are: "(1) Opportunity for Local Self-Expression, (2) The Development and Use of Local Talent, (3) Programs for Children, (4) Religious Programs, (5) Educational Programs, (6) Public Affairs Programs, (7) Editorialization by Licensees, (8) Political Broadcasts, (9) Agricultural Programs, (10) News Programs, (11) Weather and Market Reports, (12) Sports Programs, (13) Service to Minority Groups, (14) Entertainment Programming." Id. These categories have been criticized as being "arbitrary, vague, meaningless, needlessly detailed, and burdensome to the station." Robinson, The FCC and the First Amendment: Observations on Forty Years of Radio and Television Regulation, 52 MinN. L. REv. 67, 113 (1967).

20 See Section IV-B, Part I of the Statement of Television Program Service, FCC Form 303 (application for renewal of broadcast station license).

21 Early in its history the FCC ruled that broadcast licensees could not editorialize. Mayflower Broadcasting Corp., 8 F.C.C. 333, 339-40 (1941). When the Commission rescinded this regulation, it required broadcasters to give fair treatment to all controversial issues. See Note, Regulation of Program Content by the FCC, 77 HARv. L. REv. 701, 708-9 (1964). Under this "fairness doctrine," the licensee has a twofold obligation: "first to speak out on controversial public issues ...., and second, an affirmative obligation to ascertain and seek out all responsible viewpoints on controversial issues and to afford the opportunity for such contrasting viewpoints to be heard." Robinson, The FCC and the First Amendment: Observations on Forty Years of Radio and Television Regulation, 52 MrNN. L. REv. 67,134 (1967). There has been some suggestion that these policies reduce rather than increase the amount of controversial broadcasting. Id. at 136-7. But see Red Lion Broadcasting Co. v. FCC, 395 U.S. 367, 392-6 (1969).

2247 U.S.C. $\$ 315$ (1964) provides: "If any licensee shall permit any person who is a legally qualified candidate for any public office to use a broadcasting station, he shall afford equal opportunities to all other such candidates for that office in the use of such broadcasting station ...." See generally Friedenthal \& Medalie, The Impact of Federal Regulation on Political Broadcasting: Section 315 of the Communications Act, 72 HARv. L. REv. 445 (1959). 
mation, ${ }^{23}$ obscene, indecent or profane language, ${ }^{24}$ and fraudulent contests. ${ }^{25}$

\section{B. The Diffusion of Control of the Mass Media ${ }^{26}$}

The FCC has long accepted the concept that the first amendment "rests on the assumption that the widest possible dissemination of information from diverse and antagonistic sources is essential to the welfare of the public."2t The Commission's attempts to enforce this conception of the public interest by favoring license applicants with fewer interests in other media have been erratic. ${ }^{28}$ During the 1940's and 1950 's, the "diversity" factor was a secondary consideration in comparative hearings, though occasionally it was determinative of the license grant. ${ }^{20}$ Since 1965 the Commission has placed more importance on this criterion, at least when there is evidence of specific abuses. ${ }^{30}$ The

2318 U.S.C. § 1304 (1964); 47 C.F.R. § 73.122 (1968).

2418 U.S.C. § 1464 (1964).

2547 U.S.C. $\$ 509$ (1964).

28 The FCC has two sets of rules concerning diversification which serve to disqualify violators from license grants. The "multiple ownership" rules preclude one party from having ownership interests in more than seven AM, seven FM, or seven TV stations anywhere in the country. The "duopoly" rules prohibit ownership of more than one station in any service in any locality. 47 C.F.R. $\$ \$ 73.35, .240, .636$ (1968). The power of the Commission to enforce these rules without a hearing was upheld in United States v. Storer Broadcasting Co., 351 U.S. 192 (1956). Ownership of fewer stations is considered a comparative not a disqualifying factor. In such comparisons, ownership interests in newspapers are considered as well.

27 Associated Press v. United States, 326 U.S. 1, 20 (1945). See also Policy Statement on Comparative Broadcast Hearings, 1 F.C.C.2d 393, 394 n.4, 5 P \& F RADIo REg. 20 1901, 1908 n.4 (1965). In diversity, the Commission is primarily interested in the effect of multiple ownership, the ownership of more than one medium of mass communication, on the dissemination of news. See note 37 infra. In line with the general regard for local programming, the handling of local news issues would seem to be of principle concern. See Cox \& Johnson, Broadcasting in America and the FCC's License Renewal Process: An Oklahoma Case Study, in 14 F.C.C.2d 1, 10-11 (1968) [hereinafter cited as Cox \& Johnson].

28 See, e.g., Note, Diversification and the Public Interest, 66 YALE L.J. 365 (1957). The fact that the primary sources of information, the mass media, are owned by different people does not necessarily lead to the conclusion that they are either "diverse" or "antagonistic." This structural approach to the first amendment has, however, received court support, see Scripps-Howard Radio, Inc. v. FCC, 189 F.2d 677 (D.C. Cir. 1951), and is analogous to the antitrust theory of economic welfare.

29 One commentator has concluded that the pattern of communications decisions was threefold. Applicants with no other media connections were preferred to equally qualified applicants with such connections to promote diversity. But members of the latter group were never denied licenses when they were sole applicants. Finally, when all else was not equal, applicants with other media ties were preferred to applicants without such ties. L.EviN, supra note 9, at 173-4.

30 See Chronicle Broadcasting Co., 17 F.C.C.2d 245, 15 P \& F Radio Reg. 20993 (1969). In 1965 the Commission issued a policy statement on comparative hearings which reemphasized the importance of diffusion of control. See text at notes 103-7 infra. 
FCC has not, however, adopted an "aggressive," "affirmative" policy on diversification which would disqualify sole applicants or all of the competing applicants for a station, if each had other media interests which created a concentration problem. ${ }^{31}$

Since there is a great deal of cross-ownership in the communications industry, ${ }^{32}$ the merits of diversification have been the subject of much "interested debate." Opponents of the policy rely on the impossibility of controlling thought or opinion and the benefits of joint ownership. If the first argument was constructed as a syllogism, both of the premises would be fallacious. The contention would be that diversification is necessary to prevent "thought control," which is present only when a monopoly exists; no communications monopoly exists (or can be imagined), therefore diversification is unnecessary. ${ }^{33}$ Since opinion molding may result from media concentration short of an economic monopoly, the major premise falls. ${ }^{34}$ The weakness of the minor premise is that it considers the country as a whole while, to a great extent, "we have become a nation of cities."35 Admittedly, a national communications monopoly is difficult to imagine. Joint ownership of a city's newspapers and television properties is, however, commonplace, $^{36}$ and it is to these facilities that we turn for an interpretation of our local, state, and national news. Distortion of information may then be a realistic concern. ${ }^{37}$

31 See, e.g., WHDH, Inc., 17 F.C.C.2d 856, 16 P \& F RaDio REG. 2D 185 (1969); Beaumont Television Corp., 17 F.C.C.2d 574, 16 P \& F Radı REg. 2d 93 (1969). Such an affirmative policy was urged in Note, Diversification and the Public Interest, 66 YALE L.J. 365, 373-90 (1957). The commentator felt that in the early years of broadcasting the absence of either radio or television service in an area might have justified the authorization of an applicant, even though his other media interests posed a concentration problem. Id. at 376. The presence of both services in almost every area of the country would seem to preclude that rationale today.

32 Cross-ownership is the ownership of more than one communications medium. For an indication of the extent of cross-ownership, see Dingell, The Role of Spectrum Allocation in Monopoly or Competition in Communications, 13 ANTrrrust BulL. 937 (1968).

33 Heckman, Diversification of Control of the Media of Mass Communication-Policy or Fallacy?, 42 Geo. L.J. 378, 389, 398 (1954).

34 See, e.g., Mahaffie, Mergers and Diversification in the Newspaper, Broadcasting and Information Industries, 13 ANTITRusr BuLL. 927, 930-I (1968). Johnson, The Media Barons and the Public Interest, ATLANTic Monthly 43, 50 (June 1968).

35 Johnson, supra note 34, at 48. "Nearly half of the American people live in the six largest states ... Those states, in turn, are substantially influenced (if not politically dominated) by their major population-industrial-financial-media centers . . . Thus to have a major newspaper or television interest in one of these cities is to have significant national power." Id.

36 See note 32 supra.

37 Inherent in the diversification policy is "the realization that news communicated to the public is subject to selection and, through selection, to editing . . ." Scripps-Howard Radio, Inc. v. FCC, 189 F.2d 677, 683 (D.C. Cir. 1951). 
It is also important to recognize the political power of those who own our media. During the debates on the Federal Radio Act, one Congressman noted that " publicity is the most powerful weapon that can be wielded in a republic ... wo we to those who dare to differ" " with the men who control it. ${ }^{38}$ Spreading that control to many different men, would seem to lead to a healthy reduction in the power which accompanies it.

Critics of the diversification policy also point to the advantages of joint ownership. They argue that in some communities proper news service is only provided when the economies resulting from the combination of the news departments of broadcasting and publishing facilities are realized. ${ }^{39}$ It is contended that these savings permit both facilities to exist: forbidding such combinations, it is argued, would reduce, not increase, the sources of information. ${ }^{40}$ Finally, reference is made to the professionalism which publishers can contribute to broadcasting. ${ }^{41}$

While the subjectivity of the final point makes it a difficult one to refute, the error in the premise of the first cannot be ignored. In what appears to be the only study conducted on the problem, one commentator concluded that the savings which result from a combined operation are almost negligible. ${ }^{42}$ The peculiar problems of the printed and aural media, with their different characteristics and appeals, and the rules of the news services, which require newspapers and broadcast media to subscribe separately, were the primary causes of the lack of savings.

While the diversification policy appears desirable, it must remain a flexible one. Different communities will present different concentration problems. ${ }^{43}$ The arguments in favor of concentration are not completely without merit, and the Commission must remain sensitive to social and economic benefits which might flow from a particular com-

38 Johnson, supra note 34 , at 44 . See also Note, Diversification and the Public Interest, 66 YALE L.J. 365,368 (1957).

39 See 98 Cong. REC. 7421 (1952) (remarks of Senator Brown); Heckman, supra note 33, at 398 .

40 See LEvin, supra note 9, at 89-90.

41 See Hearings, supra note 10 , at 2330.

42 Levis, supra note 9, at 91-92. The industry, in response to the new Commission pressures on concentrated ownership, is preparing a study on the effects of concentration on news accuracy. See Three Billion Dollars in Stations Down the Drain?, 76 Broadcasting 19, 20 (Feb. 3, 1969).

43 The Commission, in recognition of the problem's variations, has established a flexible test for concentration. See Policy Statement on Comparative Hearings, 1 F.C.C.2d 393, 3945, 5 P \& F RAdio REg. 2D 1901, 1919 (1965). See also H. FrIENDLy, ThE FEDERAL AdMINISTRATIVE AGENCIES 68-69 (1962). 
bination. A presumption in favor of diversifying control nevertheless seems wise.

\section{Traditronal License Renewal: Denial for "Fault"}

\section{A. The Legal Theory}

The express terms of the Federal Communications Act as well as its statutory history establish beyond question the temporary nature of the broadcast license. ${ }^{44}$ The license term is limited to three years ${ }^{45}$ and, though the licensee may renew, ${ }^{46}$ he expressly waives any claim to the use of a frequency predicated on prior use. ${ }^{47}$ To remove all doubt, the Act states as its purpose the provision of broadcast channels for the use "but not the ownership thereof" by licensees. ${ }^{48}$

The Communications Act places the licensee in the same position as one seeking an initial license grant when he requests renewal. Both must demonstrate that the grant or continuation of a license will serve the public interest, convenience, and necessity. ${ }^{40}$ If either is challenged by a mutually exclusive application, the Commission must hold a comparative hearing prior to any award. ${ }^{50}$ In theory, then, an applicant seeking to replace a licensee at the time of renewal has no burden of overcoming any presumptions in favor of his opponent.

\section{B. The Practicalities}

While recognizing the legal right of an applicant to challenge a licensee when he requests renewal, the Supreme Court has taken note

44 Senator Dill, one of the primary supporters of the first law to regulate broadcasting, argued that the basic principle of frequency allocation, the public interest, convenience and necessity, precluded licensee contentions of vested rights. 68 CoNG. REc. 3027 (1927).

$4547^{\circ}$ U.S.C. \& 307(d) (1964).

$46 I d$.

4747 U.S.C. $\$ 304$ (1964) provides: "No station license shall be granted by the Commission until the applicant therefor shall have signed a waiver of any claim to the use of any particular frequency or of the ether as against the regulatory power of the United States because of the previous use of the same, whether by license or otherwise."

4847 U.S.C. $\$ 301$ (1964) provides: "It is the purpose of this chapter . . . to maintain the control of the United States over all the channels of interstate and foreign radio transmission; and to provide for the use of such channels, but not the ownership thereof, by persons for limited periods of time, under licenses granted by Federal authority, and no such license shall be construed to create any right beyond the terms, conditions, and periods of the license. ..."

Ownership of a broadcast frequency would seem to be a contradiction in terms. See Segal \& Warner, "Ownership" of Broadcasting "Frequencies": A Review, 19 RockY MT.

- L. REv. 111 (1947).

49 Compare 47 U.S.C. § 307(a) (1964) with 47 U.S.C. \$ 307(d) (1964).

50 In Ashbacker Radio Corp. v. FCC, 326 U.S. 327 (1945), the Supreme Court construed the Communications Act to require a comparative hearing whenever mutually exclusive applications are filed for a single broadcast license. 
of "how difficult it is for a newcomer to make the comparative showing necessary to displace an established licensee." 51 Inability to displace operating broadcasters is not inherent in government management. In the early years of regulation, the Federal Radio Commission often refused to renew licenses. ${ }^{52}$ Even then, however, the refusal was less the result of the competition of a new applicant than of the desire to reduce the absolute number of broadcasters and the concomitant electrical interference..$^{53}$

Although the frequency with which license renewal applications are denied does not necessarily imply the absence of FCC policy enforcement, ${ }^{54}$ it is a likely cause of the scarcity of competing applications to license renewals. ${ }^{55}$ The apparent bias in favor of license renewals was both considered and encouraged by the District of Columbia Circuit Court. In Chicago Federation of Labor v. FRC, ${ }^{56}$ the court affirmed a Radio Commission refusal to change the broadcast frequency of station WCFL, since the change would displace existing licensees. The court said that:

It is not consistent with true public convenience, interest, or necessity that meritorious stations . . . should be deprived of broadcasting privileges when once granted to them ... unless clear and sound reasons of public policy demand such action. ${ }^{57}$

Putting the burden of proving such public policy on the supporters of the new applicant would seem to establish a presumption in favor of license renewals when the licensee's broadcast record is satisfactory.

In Journal Co. v. $F R C,{ }^{58}$ the Circuit Court remanded for recon-

51 Id. at 332 .

52 Under the Radio Act, 150 AM broadcasters out of the 732 operating prior to 1927 surrendered their licenses. 1959 FCC ANN. REP. 14.

53 LEVIN, supra note 9, at 198, and cases cited therein.

54 Renewing a license for a short term, designating a renewal application for a hearing, issuing cease and desist orders, and fining the licensee are methods of correcting licensee conduct by warning him of Commission displeasure. The latter two methods are not connected to the renewal procedure and are normally initiated by private complaint, since the Commission staff is inadequate to monitor the operation of all broadcast stations. See note 80 infra. Each license submitted for renewal is liable to the first two sanctions. Such sanctions, however, are rarely resorted to. See, e.g., 1968 FCC ANN. REP. 117-20. One explanation is the cursory review of renewal applications which may result from a Commission regulation, 47 C.F.R. $\$ 73.34$ (1968), requiring all of the license renewals from a single state to be considered at the same time. See Cox \& Johnson, supra note 27, at 4.

55 Under the Ashbacker doctrine, when two parties apply for a single frequency, a comparative hearing must be held. See Notice of Proposed Rule Making, P \& F Rabro Reg. Current Serv. 51:7, 10 (1969).

5B 41 F.2d 422 (D.C. Cir. 1930).

57 Id. at 423.

8848 F.2d 461 (D.C. Cir. 1931). 
sideration a Commission permit of increased power to a station sharing the same frequency as the petitioner's station, WTMJ. The increase in power had caused electrical interference with WTMJ, resulting in a diminution of its service area. ${ }^{59}$ The court held that the interest of the public and of common justice prevented the FRC from injuriously affecting the status of a broadcast station operated in good faith. ${ }^{60}$ It ordered the Commission to reestablish WTMJ in the position it occupied prior to the acts complained of.

Relying on these two cases, the District of Columbia Circuit Court in WOKO, Inc. v. FCC ${ }^{61}$ reversed the Commission's decision to refuse renewal of the appellant's license. The court found the grounds of the refusal, licensee misrepresentation to the Commission, inadequate to overcome the public interest in the continued operation of a station providing adequate service. ${ }^{62}$ The court's position on license renewal has led one commentator to contend that "legal rights or equities flow from a license and must be considered by the Commission in the exercise of its jurisdiction."63

The bias in favor of the licensee was manifested in the weighting of the criteria considered by the Communications Commission in comparative renewal hearings. This weighting reflected both a commonsense appraisal of the comparative merits of the competitors and a recognition of the "equities" created by the courts. The FCC considered the past broadcast record of the licensee, on the station for which he sought renewal, the most persuasive evidence he could present. ${ }^{64}$ Commentators have concluded that this factor was often de-

59 There is little difference between reducing the area served by a licensee and revoking his license. See Evangelical Lutheran Synod v. FCC, 105 F.2d 793, 795-6 (D.C. Cir. 1939).

6048 F.2d at 463 .

61153 F.2d 623, rev'd on other grounds, 329 U.S. 223 (1946). On the surface the cases would seem distinguishable. That is a broadcaster might be conceded to have a "right" to non-alteration of the express provisions of his license during his three-year term, without having any "right" to have that license renewed. The cases, considered together, seem to stand for the proposition that during or at the end of a license period, when the Commission computes the public interest, it must give substantial weight to the fact that one party has a past record of satisfactory operation on a frequency which will be affected by the decision.

62 Id. at $629-30$.

63 H. WARner, Radio and Televusion Law 720 (1948.) See also Broadcasting Serv. Organization, Inc. v. FCC, I7I F.2d 1007 (D.C. Cir. 1948); Churchill Tabernacle v. FCC, 160 F.2d 244 (D.C. Cir. 1947); United States Broadcasting Corp., 2 F.C.C. 208, 236 (1935) (dictum). The Commission apparently recognizes gradations in the weight of the equities depending upon the circumstances under which the initial license was granted. See L.B. Wilson, Inc., 37 F.G.C. 511, 2 P \& F RADIo REg. 2D 653 (1964), aff'd sub nom. South Florida Television Corp. v. FCC, 349 F.2d 971 (D.C. Cir. 1965).

64 See, e.g., L.B. Wilson, Inc., 37 F.C.C. 511, 2 P \& F RADIo REg. 20 653 (1964), aff'd sub nom. South Florida Television Corp. v. FCC, 349 F.2d 971 (D.C. Cir. 1965). 
terminative. ${ }^{65}$ In the parlance of the Commission, the past performance of the licensee was a better indication of his future service than the promises of his competitor. As one commissioner phrased it,

To hold otherwise would permit a new applicant to submit a "blue sky" proposal tailor-made to secure every comparative advantage while existing licensee [sic] must reap the demerits of hand-to-hand combat in the business world, and the community it serves, in which it is virtually impossible to operate without error or complaint ....66

These arguments are persuasive, but the Commission carried them too far. The Commission in its initial grants and renewal proceedings is primarily concerned with two factors: responsiveness to local programming needs and diversification of control of the news media. ${ }^{67}$ The first factor can best be determined by prior conduct. Good performance in this category might overcome a deficiency in the second category. The Commission has, however, in the few comparative hearings involving diversification, permitted a broadcast record no better than average to overcome a serious problem of media concentration. ${ }^{68}$ Perhaps in recognition of the court-created equities, the Commission permitted prior operation alone, if not substandard, to secure a renewal for the broadcaster. Acknowledgment of this regulatory policy has apparently served to dissuade all but a few competing applicants. ${ }^{69}$

The theoretical "equities" promoted by the courts and the criteriaweighting engaged in by the Commission have created a system of "renewal without fault." The licensee who is placed into a hearing survives unless his programming is offensive, ${ }^{70}$ or unless he misrepre-

65 LEviN, supra note 9, at 187. See generally Comment, Impact of Quality Programming on FCC Licensing, 23 LA. L. REV. 85 (1962).

66 WHDH, Inc., 16 F.C.C.2d 1, 25, 15 P \& F RAdio REg. 2D 411, 435 (1969) (dissenting statement of Commissioner Robert E. Lee).

67 See text at notes $1-43$ supra.

88 See, e.g., Hearst Radio, Inc., 15 F.C.C. 1149, 6 P \& F Radio REg. 994 (1951). There, the challenging applicant was judged superior to the licensee in its integration of ownership and management, its local ownership and its diversification of stockholders' backgrounds, the normal evidence used to establish ability to fulfill local programming needs. Also, while the challenger had no broadcasting or newspaper interests, Hearst had several, some in the area served by the station desired. Hearst's program record appeared no better than average. See also Wabash Valley Broadcasting Corp., 35 F.C.C. 677, 1 P \& F RADio REg. 2D 573 (1963).

09 See Wabash Valley Broadcasting Corp., 35 F.C.C. 677, 687, I P \& F RADIo REg. 2D 573,583 (1963).

70 The first time in recent years the FCC denied a renewal primarily on programming considerations was in 1962. Eleven Ten Broadcasting Corp., 32 F.C.C. 706, 22 P \& F Radio REG. 699 (1962). 
sents facts to the Commission. ${ }^{71}$ Failure to operate a station, ${ }^{72}$ extreme financial difficulties, ${ }^{73}$ or similar licensee errors $^{74}$ may also lead to a denial of renewal. The Commission's decisions which award renewals to those whose programming is adequate and the court's "equities" which favor renewal in the absence of "clear . . . reasons of public policy" have created a process in which only failures or weaknesses on the part of the present broadcaster cost him his license. The more favorable proposals of the competing applicant, or his lack of other media connections, do not overcome an adequate operation by the licensee.

\section{The Renewal Procedure and the Implementation of Commission Policies}

The traditional renewal procedure has served to eliminate comparative considerations from renewal hearings. This has seriously limited the role of the renewal procedure as a means by which the Commission can implement its stated policies. The Commission has often relied on private complaint to enforce its programming policies. ${ }^{75}$ It is unrealis-

71 See, e.g., WMOZ, Inc., 36 F.C.C. 201, 1 P \& F RAdio REg. 2D 801 (1964); Jefferson Radio Co., 35 F.C.C. 331, 24 P \& F Rabio REg. 1033 (1963).

72 See, e.g., 1964 FCC ANN. REP. 51-56.

73 See, e.g., Boston Broadcasting Co. v. FRC, 67 F.2d 505 (D.C. Cir. 1933); Sproul v. FRC, 54 F.2d 444 (D.C. Cir. 1931).

74 WWIZ, Inc., 36 F.C.C. 561, 3 P \& F RADIo REG. 20 316 (1964) (unauthorized transfer of control of the station); WMOZ, Inc., 36 F.C.C. 201, 1 P \& F RADro REc. 2D 801 (1964) (falsification of entries into the program logs).

75 The role of private complainants in the renewal procedure was recently increased. In Office of Communication of United Church of Christ v. FCC, 359 F.2d 994 (D.C. Cir. 1966), the District of Columbia Circuit Court held that the FCC must grant standing to "responsible representatives of the listening public" to intervene and dispute the renewal of a broadcast license. In Joseph v. FCC, 404 F.2d 207 (D.C. Cir. 1968), the court indicated that such a representative need not be affiliated with any group and the allegation that the plaintiff was "typical of a substantial class of listeners" was sufficient to establish a "prima facie standing," which may be difficult for the Commission to disprove. See Standing to Challenge an Administrative Order-What Hath Church of Christ Wrought?, 57 GEo. L.J. 631 (1969). Although this expansion of standing is seen by some commentators as a great boon to the Commission's supervisory role, Note, Standing of Television Viewers to Contest FCC Orders: The Private Action Goes Public, 66 CoLum. L. REv. 1511 (1966), the opposite may result. Private complainants who are not seeking the license for themselves are apt to be poorly financed and to have great difficulty in presenting their arguments to the hearing examiner. Unless these complainants receive a great deal of aid from lawyers from the FCC's Broadcast Bureau or from those who are seeking the license, the results may prove unfortunate for the intervenors. Thus in Church of Christ, the court reversed the one-year short-term renewal the Commission had given to station WLBT and ordered the FCC to permit the complainants to prove their charges of racial and religious program discrimination. After the hearings, the Commission awarded the station a threeyear renewal. The court, however, once again reversed the FCC's decision and directed the FCC to invite new license applicants. Office of Communications of the United Church of Christ v. FCC, No. 19,409 (D.C. Cir., June 20, 1969). 
tic to assume that the Commission could maintain a staff large enough to monitor the daily broadcasts of the thousands of presently operating radio and television stations. ${ }^{76}$ Since private individuals seem increasingly willingt7 to complain about allegedly objectionable programming, the system has proved workable. ${ }^{78}$

The Commission forwards those complaints it receives to the offending licensee. Depending upon the nature of the complaint, the licensee may provide time for the discussion of the other side of an issue, alter its future programs, or explain its failure to do either to the Commission. Since his response to the complaint is considered when he requests renewal, the broadcaster is likely to comply with the complaint rather than risk losing his valuable license. ${ }^{79}$ One commentator has called this ad hoc supervision "regulation by raised eyebrow." 80 Aside from this deterrent role, the traditional renewal procedure has apparently encouraged some compliance with the local programming policy merely by the structuring of the application form. ${ }^{81}$

Three important methods of enforcing Commission policies are impeded by insulating the licensee from comparative hearings. The enforcement of the local programming policy is hindered by the inability

76 The only monitoring carried on by the FCC is designed to "detect and suppress potential or actual interference to authorized radio stations [and] to locate or confirm the positions of distressed vessels and aircraft." 1967 FCC ANN. REP. 107. Apparently the monitoring attempts to pick up a radio signal and not the content of that signal.

77 See 1968 FCC ANN. REP. 44.

78 The primary criticism of the system is that it may be too effective, greatly curtailing broadcaster freedom in a sensitive first amendment area. See Kalven, Broadcasting, Public Policy and the First Amendment, $10 \mathrm{~J}$. LAw \& Econ. 15, $21-23$ (1967).

$70 \mathrm{I}$ K. C. Davis, Administrative LAW Treatise $\S 4.03$ (1958); Kalven, supra note 78, at 21-23.

80 I K. C. Davis, Administrative Law Treatise \& 4.03, at 242 (1958) (quoting Commissioner Doerfer's dissenting statement in Miami Broadcasting Co.). Commentators have not resisted comparing this use of the renewal power to a "Sword of Damocles." See Robinson, The FCC and the First Amendment: Observations on Forty Years of Radio and Television Regulation, 52 MrN. L. REv. 67, 119 (1967). Congress has supplied the Commission with various other tools which could be used, in lieu of renewals, to enforce valid complaints. These complaints primarily concern vulgar programming or the "unfair" presentation of a controversial issue, see, e.g., 1968 FCC ANN. REP. 44, which are prohibited by congressional and Commission regulation. Violations of such regulations can be penalized by license revocations or cease and desist orders, 47 U.S.C. $\S 312$ (1964); and by monetary forfeitures. 47 U.S.C. $\S \S 501-4$ (1964). The use of the renewal power to enforce policies which can be reduced to rules is thus superfluous. Its primary advantage seems to be circumventing judicial review.

81 See, Robinson, supra note 80, at 111-5. Part I of the Statement of Television Program Service section of the application form asks the applicant to "State . . . the methods used ... to ascertain the needs and interests of the public served by the station [and to identify] representative groups, interests and organizations which were consulted." $\mathrm{He}$ is also required to list typical programs he has broadcast "which have served public needs and interests." FCC Form 303, Section IV-B, Part I. 
of the Commission to secure reliable information from the licensee on the needs of his service area. "The licensees describe the . . . unscientific methods they have employed to divine the needs of their community. These needs are often not specified. When specified, they often have little relation to the programming decisions the licensee has made."82 Permitting a competitor to submit his information on the programming desires of the service area would seem likely to increase the informative nature of both applications and to reduce the FCC's tendency to rubber-stamp the licensee's program proposals. Such competition is also likely to increase the desire of interested local groups to submit their suggestions to the Commission. By turning the comparative hearing into a dialogue between responsible representatives of the service area and applicants competing for the examiner's favor, both knowledge of local needs and programming consistent with those needs should expand. ${ }^{83}$

Commission concern for the structure of the communications industry has been virtually ignored in the traditional renewal procedure. Deficiencies in the integration of ownership and management, an evidentiary component of local programming, ${ }^{84}$ and in the diffusion of control of the communications media have been overcome without difficulty by a challenged licensee. ${ }^{85}$ To the extent that this renewal procedure deterred challenges entirely, integration and diversification went unenforced. 86

The inability to reduce these structural objectives to concrete rules accounts for their neglect in the non-comparative hearing. Thus, with

82 Cox \& Johnson, supra note 27 , at 9 .

83 The need for increased information from local groups has been recognized by both the courts and the Commission. See Office of Communication of the United Church of Christ v. FCC, 359 F.2d 994 (D.C. Cir. 1966); Report of Commissioner Henry on Local PRogramoming, summarized in 1963 FCC ANN. REP. 60-61.

84 The full-time participation in station operation by owners, the integration of ownership and management, is a factor of "substantial importance" to the Commission. See generally Policy Statement on Comparative Broadcast Hearings, 1 F.C.C.2d 393, 394, 5 P \& F RADIO REG. 2D 1901, 1909-10 (1965). Such integration is presumed to render more likely the effectuation of program proposals by closely associating those who are granted the license with those who actually operate the station. Since programming proposals are attuned to the FCC's bias for local programming, a presumption that proposals will be carried out is a presumption that programming will be locally oriented. Attributes of participating owners, such as their local residence and their participation in local activities are also considered in weighing the importance of the integration factor. These local contacts are considered indicative of the licensee's ability to serve as a "mouthpiece" for its community. See H. Friendly, The Federal Administrative Agencies 58-67 (1962).

85 See note 68 supra.

86 See, e.g., Note, Diversification and the Public Interest, 66 YALE L.J. 365, 379 n.88 (1957). 
diversity, no congressional or Commission rule ${ }^{87}$ could provide more than a guideline to govern consideration of the different problems multiple ownership causes in different areas. And, it seems unlikely that the Commission would enforce a guideline as strictly in a sole as in a comparative hearing. ${ }^{88}$

Several reasons have been suggested for insulating licensees from comparative challenges by competing applicants. Recitations of the large investments made by the broadcasters, which presumably take more than three years to earn back, have often buttressed those court opinions which supported license equities. ${ }^{89}$ While this consideration might have been valid during the early years of broadcasting, when revenues were small and profits often non-existent, the same rationale continues into the present day, ${ }^{90}$ though television broadcasters' earnings average 100 per cent of investment annually..$^{91}$ In addition, as some commentators have observed, the argument that licensee equipment investments should preclude denial of its renewal application is, at most, an argument against denial without compensation. ${ }^{92}$ Were the Commission to require successful challengers to reimburse defeated licensees for the fair market value of their tangible investments, this argument would seem to be met. ${ }^{93}$

87 The courts have construed the Communications Act to deny power to the Commission to prohibit all newspaper owners from acquiring broadcast stations. See Stahlman v. FCC, 126 F.2d 124 (D.C. Cir. 1942); 98 Cong. REc. 7417-21 (1952). Thus the Commission's multiple ownership rules, see note 26 supra, ignore an applicant's newspaper ownership.

88 At a sole renewal hearing disqualification results only when the grant would be contrary to the public interest. This standard seems likely to permit more cross-ownership than the comparative hearing in which even a grant to the loser would serve the public interest though to a lesser extent than the grant to the winner. See Note, Diversification and the Public Interest, 66 YALE L.J. 365, 373 (1957).

89 See Evangelical Lutheran Synod v. FCC, 105 F.2d 793 (D.C. Cir. 1939); Journal Co. v. FCC, 48 F.2d 461 (D.C. Cix. 1931).

oo See WHDH, Inc., 16 F.C.C.2d 1, 25, 15 P \& F RADIo REg. 2d 411, 436 (1969) (dissenting opinion).

91 See Johnson, The Media Barons and the Public Interest, AtLantic Monthly 43, 48 (June 1968). Cox \& Johnson, supra note 27, at 10. The investment referred to is tangible investment which may be much less than the high price often paid to a broadcaster to purchase his license. See Coase, The Federal Communications Commission, 2 J. LAw \& ECON. 1 (1959). The distinction between the two types of "investment" is significant. The quality of the broadcast service will presumably bear some relationship to the investment in equipment. If comparative considerations at renewals prevented the recoupment of this expenditure, the public interest would not be served since a reduction in investment would be the likely result. While comparative considerations at renewals may prevent broadcasters from recovering the price paid for their license, it is difficult to see how the public interest is injured by this. The only effect should be the reduction of future sales prices.

92 A. DeVany, R. Eckert, C. Meyers, J. O'Hara \& R. Scott, Electromagnetic Spectrum MANAGEMENT: ALTERNATIVES AND Experiments 15 (1968).

93 Compare LEvin, supra note 9, at 188. 
It has also been suggested that a switch to truly comparative renewal hearings would, through ending the permanent status of the license, increase the Commission's role as a censor. ${ }^{94}$ This contention is based on a misconception of the implications of the statistics on renewal denials. The "automatic" renewal grant is often obtained only after broadcaster concessions to Commission complaints on specific programs. ${ }^{95}$ One function traditionally served by the renewal is to enforce those complaints. Censor-free regulation can only exist when program review enforced by effective sanctions is absent. Such review is as evident in the traditional as in the comparative renewal.

There is one argument that cannot be ignored, however, by those who seek the advantages of comparative renewal hearings. Basing license renewals on past performance would seem to act as the primary incentive for programming improvements and investments. Any renewal system which reduces the importance of this prior operation seems likely to reduce the level of program investment and the quality of broadcast services. ${ }^{96}$ In a renewal system based on past performance, the clearer the standards of acceptable operation, the more likely is compliance with them, and the present renewal-without-fault procedure aids in maintaining the clarity of these standards. In a comparative renewal system the broadcaster could not know if he had performed adequately until his competitor's proposals were presented. The insecurity resulting from the vagueness of the required standards of operation would be likely to reduce industry investment and the level of program service. The clarity of these standards is only gained, however, by sacrificing the constant improvement of them. And, if broadcaster security is so high that renewals become automatic, incentives to improve are likely to decrease.

\section{BEYOND FAULT}

Recent FCC actions indicate an increasing desire to use the renewal hearing as a comparative forum to better effectuate national communications policies. After an examination of the circuitous manner

\footnotetext{
94 See, e.g., Lyndon, FCC License Renewals: Rubber Stamp Is Gone, New York Times, April 27, 1969, at 72, col. 3 .

95 See text at notes 77-80 supra. The only new programming regulation which would be introduced by comparative considerations, local programming, is not inconsistent with first amendment guarantees. See notes 13 \& 14 and accompanying text supra.

96 Levin, supra note 9, at 187; Levin, Federal Control of Entry in the Broadcast Industry, 5 J. LAW \& ECON. 49 (1962). See also Hale \& Hale, Competition or Control II: Radio and Television Broadcasting, 107 U. PA. L. REv. 585, 591 (1959). "Both the Commission and the courts have recognized that failure to renew the bulk of the licenses would ... discourage the rendering of good service." Id. at 591. See generally Jaffe, WHDH: The FCC and Broadcasting License Renewals, 82 HARv. L. REv. 1693 (1969).
} 
in which the Commission altered its position, criticisms of the new renewal procedure will be considered.

\section{A. The Evolution of the Comparative Renewal Hearing}

We haven't the slightest notion where we're going . . . but we know we're getting there a whole lot faster than ever before. ${ }^{97}$

In the last decade the Commission has been prompted to reform its spectrum allocation procedures by the criticisms of respected critics. In his report on the regulatory agencies to incoming President Kennedy, Professor James Landis said that the Commission presented an "extraordinary spectacle" and that "it seems incapable of policy planning ... of fashioning procedures that are effective to deal with its problems" in the initial allocation of licenses. ${ }^{98}$

Judge Henry Friendly found that the Commission had often confused its policies with the factors which compose them and suggested that diversity of control of the mass media and local programming were its two primary objectives. ${ }^{99} \mathrm{He}$ concluded that, sub silentio, the FCC had permitted the past broadcasting record of the licensee to override the diversity and local programming objectives, though this tendency was subject to exception. ${ }^{100}$

Recently the District of Columbia Circuit Court seems to be preparing to remove its support from the license equities it once so ardently championed. ${ }^{101}$ Not only has there been an absence of the judicial language which previously supported renewal applications, but the court, as if to warn the FCG, has specifically conditioned the affirmation of license grants in analogous situations on the absence of Commission preference for prior operation. ${ }^{\mathbf{1 0 2}}$

In 1965 the Communications Commission issued its Policy State-

\footnotetext{
a7 Johnson, Harnessing Revolution: The Role of Regulation and Competition for the Communications Industries of Tomorrow, 13 ANTrTRust BuLx. 881 (1968).

98 J. Landis, Report on Regulatory Agencies to the Presment-Elect, 86th Cong,, 2d Sess. 53 (1960).

98 H. Friendly, The Federal Administrative Agencies 57-58 (1962).

100 Id. at $60-64$.

101 See notes 56-63 and text accompanying supra.

102 In Miners Broadcasting Service, Inc. v. FCC, No. 21,937 (D.C. Cir. March 20, 1969), the court affirmed the Commission's grant of an initial license only after finding that the FCC had not considered any evidence derived from the operation by the grantee of its existing station. In its brief, the FCC, perhaps aware of the court's new views, had insisted that the challenged evidence had not been relied upon. "Fad the Commission attached probative significance to the fact that in certain areas Monroeville's [the grantee] showing was based on actual experience and Miners' showing in the same areas was not, [the] claim of prejudice might have a basis in fact .... Miners showing was in no sense discounted because it did not reflect an actual operation." Brief for appellee at 21, id.
} 
ment on Comparative Broadcast Hearings. ${ }^{103}$ The Policy Statement focused on the problems of initial allocations of broadcast licenses. It did "not attempt to deal with the somewhat different problems raised where an applicant is contesting with a licensee seeking renewal of license."104 Conforming fairly closely to the suggestions of its critics, the Commission announced that its two primary objectives were maximizing diffusion of control of the communications media and according the best practicable service to the public. The latter was equated to "a broadcast service which meets the needs of the public in the area to be served."105 In addition, the FCG decided that the past broadcast record of an applicant would be ignored unless it was either unusually good or bad. ${ }^{106}$ Given the historical context of the statement, a superior record would probably overcome diversity or local programming deficiencies, while an inferior record would be fatal. ${ }^{107}$

Several months later the Commission extended the scope of the Policy Statement to cover comparative renewal hearings, an extension buried deep in an order to hold a comparative hearing on the renewal application of a licensee in financial difficulties. ${ }^{108}$ Finally, in $W H D H$, Inc., ${ }^{109}$ a comparative renewal hearing was governed by the criteria described in the Policy Statement. Assessing the licensee deficiencies in the diversification and the integration of ownership and management categories, the Commission refused to renew its television license. ${ }^{110}$ The average broadcast record of the licensee, which, in the

1031 F.C.C.2d 393, 5 P \& F Radio REg. 2D 1901 (1965).

104 Id. at 393 n.1, 5 P \& F RADio REg. 2D at 1907 n.1.

105 Id. at 394, 5 P \& F Radio Reg. 2D at 1908.

106 Id. at 398, 5 P \& F RADIo REg. 2D at 1912.

107 Though often used by the Commission, such terms as "inferior," "adequate," and "superior" programming seem not to have precise meanings. Through increasing FCC knowledge of local programming needs, comparative hearings may enable the Commission to give the terms some content by establishing different levels of local need fulfilment. Since structural problems of diversity or integration are presumed to lead to improper programming, see text at notes 26-28, 84 supra, it would appear reasonable for the Commission to insist upon higher standards of programming from those with structural defects. But see note 122 infra.

108 Seven (7) League Productions, Inc., 1 F.G.C.2d 1597, 5 P \& F Radro REg. 20 991 (1965).

10916 F.C.C.2d 1, 15 P \& F Radio REg. 2D 411 (1969).

$110 \mathrm{Id}$. at 17, $15 \mathrm{P} \& \mathrm{~F}$ Radio REg. 2D at 427. There are several factors which may be relied upon to minimize the effect of this decision. In general, the doctrine of stare decisis does not apply to administrative agencies. See Kentucky Broadcasting Corp. v. FCC, 174 F.2d 38, 40 (D.C. Cir. 1949). Specifically, the "equities" ignored in the opinion may not have been substantial. The appellate court had twice before vacated license grants to WHDH: Greater Boston Television Corp. v. FCC, 334 F.2d 552 (D.C. Cir. 1964); Massachusetts Bay Telecasters, Inc. v. FCG, 261 F.2d 55 (D.C. Cir. 1958). In the instant case the Commission was to reconsider its 1962 license grant (vacated in 1964) as well as the WHDH application for renewal of that license. The Commission decided the latter issue and, save by implication, ignored the former. 
past, would have overcome integration and diversification deficiencies $^{111}$ was, in line with the Policy Statement, ignored.112

Perhaps because it had viewed the 1965 decree as another ringing statement which the Commission would ignore at the first opportunity, the broadcast industry had given it little note.113 WHDH, however, indicates the Commission has, in fact, "changed the rules" of comparative renewal hearings. By removing the cushion which a merely satisfactory record had provided, the Commission now exposes licensees to the superior proposals of competitors. With a much improved chance of emerging victorious, competing applicants are expected to file in increasing numbers. 114

Regardless of the substance of the modification, the manner in which it was accomplished was unfortunate. The Commission gave no public consideration to the effect of the new criteria on the license equities it had allowed to exist; nor did it discuss why competitive renewal hearings, which raise "somerwhat different problems," 115 should be governed by the same criteria as initial license grants. As it stands, the Commission position on renewals seems more a tactic designed to provoke a congressional response than a well-rounded policy proposal.

\section{B. The Congressional Response}

If the renewal alteration suggested by $W H D H$ is carried out, the effect on ownership interests in the industry will be drastic. One hundred twenty-seven television licensees out of the 184 in the top 50 markets have structural problems which leave them vulnerable to a comparative challenge. ${ }^{116}$ While the claims of any one licensee to protection because of reliance on past Commission practice can be ignored, the arguments of virtually the entire industry for such protection may well drown out those who see advantages in comparative hearings. ${ }^{117}$ By threatening the vested interests of so many in such a

\footnotetext{
111 See text at notes $69 \& 70$ supra.

11216 F.C.C.2d 1, 13, 15 P \& F RADIO REg. 2D 411, 424-5 (1969).

113 For example, Broadcasting Magazine, a zealous protector of industry interests, did not editorialize on the statement nor were its news stories other than informative.

114 See WHDH, Inc., 16 F.C.C.2d 1, 27, 15 P \& F RADIo REg. 2D 411, 439 (1969).

115 See text at note 104 supra.

116 Three Billion Dollars in Stations Down the Drain?, 76 Broadcasting 19, 21 (Feb. 3, 1969). These "stations are involved in "co-located ownership with another communications medium.' Of the 715 AM and FM stations in [the top fifty] markets, 526 face the same threat." $I d$.

117 Primarily, this reliance is indicated by the prices paid for licenses when they are sold. "At present, market trading bids up the buyer's capital costs by an amount equal to the capitalized value of his [and the seller's] earnings expectations over the total expected duration of channel occupancy on the ... assumption that FCC will renew the buyer's license almost automatically any desired number of times." Levin, Federal Control of Entry in the Broadcast Industry, $5 \mathrm{~J}$. LAw \& EcoN. 49, 60 (1962).
} 
politically powerful industry, the Commission may lose the opportunity to make renewal hearings more effective in policy implementation. It is important to remember that while a concession to license equities may not be "a principle of law or economics, it comes close to being a law of politics." 118 The absence of a politically potent countervailing force is manifest. Additionally, the new procedure seems to give insufficient attention to the insecurity which it will cause in the broadcast industry. A decline in program investment seems likely if no licensee is able to predict precisely what actions will insure the renewal of his license. ${ }^{119}$

The broadcast industry, with the support of at least one powerful Senator, ${ }^{120}$ has urged a return to the renewal-without-fault procedure. The industry plan would require the FCG to find that a grant of the renewal would not be in the public interest prior to considering a competing application. ${ }^{121}$ Since a finding of fault would precede any comparative hearing, the proposal would effectively overrule the recent FCG renewal modification. A licensee who avoided the failures discussed above would be granted a renewal regardless of the better proposals and lesser media contacts of a potential rival. ${ }^{122}$

In essence, the proposed legislation would provide for congressional affirmation of the equities so recently disavowed by the District of Columbia Circuit Court and the FCC. Licenses, once granted, would

118 John Poole Broadcasting Co., Inc., 16 F.G.G.2d 458, 463, 15 P \& F RADio REg. 20 609, 615 (1969) (dissenting opinion).

119 See text following note 96 supra.

120 Senator John O. Pastore (D-R.I.), Chairman of the Senate Communications Subcommittee. Pastore has long been concerned with allegedly vulgar programming. Critics have suggested that Pastore is willing to give the industry his aid in restraining the FCC in return for the broadcasters' agreement to submit their programs to a pre-screening review by an industry board. See Brown, Television Enters 'Code' Era, Variety, March 26, 1969 , at 74 , col. 1. If this is true, then only the public suffers as automatic licenses are traded for first amendment rights.

121 A Law to Deter Strike Applications?, 76 Broadcastrng 34 (March 21, 1969). The proposed legislation reads as follows:

Be it enacted by the Senate and House of Representatives of the United States of America in Congress assembled, that section 309(a) shall be amended by adding the following after the final sentence thereof: "Notwithstanding any other provision to the act, the commission, in acting upon any application for renewal of license filed under section 308, may not consider the application of any other person for the facilities for which renewal is sought. If the commission finds that the public interest, convenience, and necessity would be served thereby, it shall grant the renewal application. If the commission determines after hearing that a grant of the application of a renewal applicant would not be in the public interest, convenience and necessity, it may deny such application, and applications for construction permits by other parties may then be accepted, pursuant to section 308 , for the broadcast service previously licensed to the renewal applicant whose reId. newal was denied."

122 Compare the result in Hearst Radio, Inc., 15 F.C.C. 1149, 6 P \& F RAdro REG. 994 (1951) discussed at note 68 supra. 
not be withdrawn without "clear and sound reasons of public policy ...."123

Justifications for such equities are not readily apparent. ${ }^{124}$ Additionally, though past congressional inactions have helped insure "automatic renewals," the legislators should find it difficult to prescribe a renewal procedure which so clearly conflicts with the theory that only comparative hearings between all of those willing to operate insures the best practicable broadcast service. ${ }^{125}$

Another plan urged by industry spokesmen would have the Commission revert to its former policy of considering favorably a licensee's broadcast record "within the bounds of average."128 This plan would have the same effect as the first proposal despite its different approach. Comparative hearings would remain, but an average broadcast record would overcome most deficiencies. ${ }^{127}$ Industry spokesmen are uncertain whether legislation or pressure on the Commission is the best method of implementing this plan. Once again, Congress should prove reluctant to repudiate openly the advantages of comparative hearings, ${ }^{128}$ and the Commission would appear to be beyond the point of easy return. ${ }^{129}$

123 Compare text at notes 25-30 supra.

124 See text at notes 89-95 supra.

125 See National Broadcasting Co. v. United States, 319 U.S. 190, 217 (1943). The Ashbacker doctrine, which requires a comparative hearing when mutually exclusive applications are filed, was based on a construction of 47 U.S.C. § 309(a) (1964). Although an applicant has no more than a privilege to a broadcast license, there is some authority for the proposition that due process requires that such an applicant be granted a hearing. See generally 1 K. C. Davis, Administrative Law Treatise $\$ \S 7.11-.12$ (1958).

126 A Law to Deter Strike Applications?, 76 Broadcasting 34, 35 (March 21, 1969).

127 See the excerpt from the opinion of the initial hearing examiner in WHDH, Inc., 16 F.C.C.2d 1, 10, 15 P \& F RADIo REg, 2D 411, 423 (1969).

128 To override the present Commission practice, Congress would have to specify the weight to be given such a record. The implications of such action for comparative renewal hearings would be clear.

129 The Commission governed the WHDH hearings by the 1965 Statement despite the existence of less abrasive methods of reaching the same result. See note 80 supra. This would seem to indicate a policy decision not easily foresaken. Whether Senator Pastore is able, through hearings alone, to intimidate the Commission is difficult to predict. If, after such hearings, Congress failed to pass legislation favorable to the broadcast industry, the Commission might feel that its policy had been ratified.

The broadcast industry can draw only slight hope from the Commission's decision denying a rehearing in the WHDH case. WHDH, Inc., 17 F.C.C.2d 856, 16 P \& F RADro REg. 2D 185 (1969). See FCC Closes Door on WHDH, 76 Broadcasting 42 (May 26, 1969). The Commission reaffirmed the use of the 1965 Statement on Comparative Hearings to govern comparative renewal hearings, and upheld its decision to ignore average broadcast performances even though "[w]e recognized that a renewal applicant must literally run on his record and such record is the best indication of future performance." Id. at 857, 16 P \& F RADIo REg. 2D at 189.

The Commission concluded a lengthy opinion with the curious statement that WHDH 


\section{A Legislative Proposal}

A renewal procedure which secured the advantages of comparative hearings without the undue threat to broadcaster security implicit in $W H D H$ seems preferable. The new procedure, which would require amendments to the Federal Communications Act, ${ }^{130}$ could be structured on the following guideline.

Initially, licenses would be granted for up to six years. After three years the licensee's record and the proposals of those who plan to challenge the licensee at the end of his term would be considered by the FCC. The Commission would extend the license for three years, giving the licensee a new six-year term, if such extension would be in the public interest, convenience, and necessity. He would then be in the position of an "initial licensee." 131

If an extension would not be in the public interest, the Commission would advise the licensee of the weaknesses in his application. The broadcaster would then have three years to improve his position. At the end of that time, the licensee might be unchallenged, challenged by one who had successfully challenged him before (a "preferred applicant") ${ }^{132}$ or by one who had not (a "competing applicant"). ${ }^{133}$ If the public interest favored the licensee or the "preferred applicant," a new

was not an "ordinary" renewal applicant because it had only a short-term license and the Commission, after the grant of the license, had invited others to compete when the licensee applied for renewal. Id. at 872-3, 16 P \& F RADro REG. 20 at 203-4. In similar cases, prior to the adoption of the 1965 Statement, the Commission had concluded that any preference on past broadcast record accorded the licensee would be given only slight weight since he was presumed to have performed better in order to enhance his position at the impending comparative renewal hearing. See, e.g., L.B. Wilson, Inc., 37 F.C.C. 511, 2 P \& F RAdio REG. 2D 653 (1964), aff'd sub nom. South Florida Television Corp. v. FCC, 349 F.2d 971 (D.C. Cir. 1965). This presumption makes little sense in the context of the post-1965 comparative renewal hearing unless the licensee's performance is above average, for only then will such performance enter into the comparison at all. The performance of WHDH did not attain this level. 17 F.C.C.2d at 857, 16 P \& F RAdro REG. 20 at 189.

The concluding statement might have related to the Commission's refusal to permit WHDH a "without-fault licensee an opportunity to dispose of his station in a reasonable and orderly fashion" to avoid the forfeiture of his investment. $I d$. at 861, 16 P \& F RADIo REG. 2D at 192. If so, there has been no suggestion by the Commission of a method in which this is to be accomplished. Nor does its refusal seem to indicate that a contrary position would be taken in a different renewal proceeding. Id., 16 P \& F RADIo REG. 2D at 192-3.

Whether the final statement was designed to retain the votes of a wavering majority or merely to confuse the Commission's harsher industry critics cannot be ascertained. That these critics are unlikely to be appeased without new legislation which would prevent "the FCC from taking ad hoc actions that can lead to wholesale divestitures" seems probable. See Boston Stake: Three Billion Dollars, 76 Broadcasting 84 (Feb. 3, 1969).

130 Proposed amendments to sections 307 and 310 of the Communications Act, 47 U.S.C. $\S 307$ (1964) and 47 U.S.C. $\S 310$ (1964) are submitted in the Appendix to this comment. 131 See Appendix $\S 307$ (d)(i).

132 See Appendix $\S 307$ (d)(iii). Since the amendment is designed to encourage broad- 
license of up to six years would issue to the one selected. If the public interest favored the "competing applicant," a license of not more than three years would be issued to the renewal applicant or the "preferred applicant." At the expiration of this term the "competing applicant" would then be a "preferred applicant" and able to secure the license for himself. As an incentive to potential applicants, the licensee would be precluded from transferring the license to other than a "preferred applicant," if one existed, during the final three years of the license term. ${ }^{134}$

The primary changes in the renewal procedure would affect licensees challenged by new applicants. Unchallenged licensees would be in approximately the same position as they are now. They would, however, have a longer license and periodic, institutionalized supervision by the Commission. ${ }^{135}$

The amendments attempt to provide sufficient incentives for an applicant to challenge, so that comparative hearings may take place, while reducing the "ambush" effect of such challenges on present broadcasters. A licensee judged to have a comparative deficiency would have three years to improve some aspect of his operation, along the guidelines established by the FCC, before losing his license. ${ }^{136}$ Thus, if his deficiency was in the diversity factor he could either sell his other

casting improvements by notifying the broadcaster of the level of performance necessary to maintain his license, it is submitted that the Commission should not permit a "preferred applicant" to present an application at the comparative hearing better than its original one. If, however, during the three-year interim its position has worsened, the change should be considered. An improved application could be treated as a separate filing by a "competing applicant" if the original application is insufficient to defeat the licensee.

133 See Appendix § 307(d)(ii).

134 See Appendix $\$ 310(\mathrm{~b})$.

135 The license is extended for six years primarily to provide the Commission with an adequate record to review and to provide the licensee with a sufficient period to improve. The attraction of the longer term to the broadcast industry was not ignored. Institutionalized review should reduce one of the major problems with the present ad hoc supervision of program content. An initial licensee notified during the first three years of his license term of a complaint about his programming will be able to ignore it without risking the loss of his license. If, at the mid-term review, the FCG refuses to extend the license because of the unsatisfied complaint, the broadcaster will be able to secure judicial review of the decision. Compare $1 \mathrm{~K}$. C. Davis, Administrative Law Treatise $\$ 4.03$ (1958). Complaints during the final years of a license term will not be so easily ignored and, during this period, Commission supervision may remain unchecked by judicial review.

136 A licensee could do this through improving his broadcast record or by increasing the integration of the ownership and the management of his station. It is, of course, possible that the extent of the licensee's deficiency in the diversity factor will preclude improvement in the programming factor sufficient to secure the license. If the Commission so informed the broadcaster, divestiture of either the contested license or of control of other media would be required during the final three years of the license term. 
media, improve his position in the local programming factor, or sell the contested license to the "preferred applicant." What each licensee does in any particular situation will presumably depend upon the ability of the licensee and the "preferred applicant" to agree upon the fair market value of the renewal applicant's challenged license. That is, a licensee defeated at a mid-term challenge could, if he chose, sell his license to the applicant who was preferred. Excluding the tangible property, the licensee would be selling the three years of operating profits he was still entitled to and the risk that he would improve his operation sufficiently to defeat the "preferred applicant" at the comparative hearing at the end of the license term. The present value of the three years of future profits can be calculated without difficulty assuming that the profits have been reasonably consistent. The value of the risk depends upon its size, which primarily depends upon the results of the mid-term hearing. Thus the greater the preference for the "competing applicant" at the mid-term hearing, the smaller the risk that the licensee will be able to improve sufficiently and the smaller the price which the licensee can receive for selling such risk. Granting the licensee the option of complying with the new performance standards set by his competition or of selling his license permits constant improvement in the Commission's standards of broadcast service and in the structure of the industry, while avoiding the excessive sacrifice of broadcaster security threatened by $W H D H .{ }^{137}$

137 Professor Jaffe, who believes that the security of investment under the present renewal system promotes the regulatory objectives of the FCC, would apparently permit competing applicants to defeat licensees in comparative renewal hearings if the vanquished licensee would be awarded the license, despite his defeat, on the condition that he sell to the victorious competitor. See Jaffe, WHDH: The FCC and Broadcasting License Renewals, 82 HARv. L. REv. 1693, 1699-1700 (1969). Jaffe has drawn his solution from two Commission decisions, Melody Music, Inc., 2 F.G.C.2d 958, 6 P \& F Radro REG. 2D 973 (1966) and National Broadcasting Co., 37 F.C.C. 427, 2 P \& F RAdio Rec. 2D 921 (1964), which he seems to conclude are contrary to statutory authority. Jaffe, supra, at 1699-1700. There are difficulties with Professor Jaffe's suggestion that Congress might amend the Communications Act to provide that authority, a necessary provision if the Commission is to issue conditional licenses on a regular basis. First, it is uncertain whether the Professor intends his "more equitable" solution to be used when a "faulty" broadcaster loses his license to a competitor as well as when an adequate broadcaster is defeated solely by the superior proposals of a competitor in a comparative renewal hearing. The problem of when to award a license to a defeated applicant is avoided, if not resolved, in this comment's solution through lengthening the license period and reviewing performance at mid-term.

Additionally, it is not clear if sale is the only condition to be attached to the license. This comment has assumed that the clearer the standards of adequate performance, the more likely is compliance with those standards. See text following note 96 supra. A threeyear "trial" period following the comparative renewal hearing was suggested as a method of providing the broadcaster with clear standards without sacrificing the advantages of 
The amendment to section 310 is designed to furnish adequate incentives to potential challengers, without whom the advantages of comparative hearings will go unrealized. ${ }^{138}$ In the absence of such an amendment, defeated licensees with serious deficiencies could sell to parties who had not incurred the expense of challenging them, and, who, for that reason alone, might be able to afford a higher price for the license. With little to gain, few would appear to challenge the licensees. The amendment is premised on the idea that the party who increases the vulnerability of the licensee should be permitted to benefit from it. Since the preference given such a party exists whether the sale results from the fear of a future renewal loss or merely from the licensee's desire to dispose of his business, the amendment should provide a sufficient inducement to potential challengers. ${ }^{139}$

comparative hearings. Professor Jaffe, perhaps because he rejects the feasibility of program regulation, Jaffe, supra at 1700 , seems to ignore the assumption stated above and to focus his solution merely on softening the defeated licensee's loss by permitting him to sell a new three-year license to his victorious opponent. No broadcaster, under the Jaffe solution, will ever be able to predict precisely what level of performance will insure the renewal of his license. If alternative conditions, similar to the options discussed in this comment, were attached to the license awarded the defeated licensee, the Professor's solution would more closely resemble the one suggested here.

138 In 1952 Congress amended the section of the Communications Act concerned with license transfers, 47 U.S.C. $\S 310(\mathrm{~b})$, to provide that the Commission should consider a potential transferee selected by the broadcaster as a sole applicant; that it should not force him into a comparative hearing with others desirous of the license to determine if the public interest would be served by the transfer. This amendment was designed to overturn the so-called AVCO Procedure which had permitted others to bid for the license. The 1952 amendment was predicated on the belief that the AVCO Procedure was "an unwise invasion by a government agency into private business practice." See S. REP. No. 44, 82d Cong., Ist Sess. (1951), reported in 12 Fn. CoMM. B.J. 127, 138 (1952). Invasions into private business practice by the Communications Commission are permitted when in the public interest. See, e.g., National Broadcasting Co. v. United States, 319 U.S. 190 (1943). The FCC, prior to the 1952 amendment had recognized that the AVCO Procedure was not operating in the public interest since it had "failed to realize the expectations . . . with respect to making possible a choice between two or more competing applications for assignments or transfers of control . . ." 14 Fed. Reg. 3235 (1949). The amendment proposed in this comment will, by increasing the incentives for applicants to compete, serve the public interest and avoid a conflict with the stated purpose of the 1952 congressional alteration.

139 A reduction in the financial burdens of comparative hearings would seem likely to increase the number of challengers. One commentator has suggested that the failure of the FCC to clarify the criteria upon which it had relied had led to an unnecessary increase in the scope of the record and the duration of the hearings. See Grunewald, Should the Comparative Hearing Process Be Retained in Television Licensing?, 13 AM. U.L. REv. 164, 165-6 (1964). The costs which resulted from such increases may have been partially reduced by the Commission's 1965 Policy Statement on Comparative Hearings which attempted to isolate the important criteria and designate the methods of proving each. Further improvements in this direction might consist of substituting oral argument for cross-examination in appropriate situations. 


\section{CONCLUSION}

$W H D H$ appears to be the culmination of a gradual FCG reappraisal of the role of the renewal power in implementing its conception of the public interest. The threat which comparative disqualification poses to vested interests in the politically powerful broadcast industry makes a congressional reaction likely. Unless Congress disapproves of the FCC's communications policies, it should be hesitant to accept the industry's proposals to return to "renewal without fault." Such renewals, by providing the licensees with an unjustified insulation from challenge, hinder policy implementation. Reluctance to see a widespread, almost total change in the nation's broadcasters, however, is understandable. The proposed amendments to the Communications Act are designed to provide Congress with an alternative to the traditional renewal procedure and to the one suggested by recent FGG actions, an alternative which takes the advantages of both into consideration.

\section{ApPENDix}

\section{A. Proposed Amendment to Section $307^{140}$}

[307(a)-(c) remain the same.]

(d) For the purpose of section (e) the following definitions are applicable:

14047 U.S.C. $\$ 307$ (1964) presently provides:

(a) The Commission, if public convenience, interest, or necessity will be served thereby, subject to the limitations of this chapter, shall grant to any applicant therefor a station license provided for by this chapter.

(b) In considering applications for licenses, and modifications and renewals thereof, when and insofar as there is demand for the same, the Commission shall make such distribution of licenses, frequencies, hours of operation, and of power among the several States and communities as to provide a fair, efficient, and equitable distribution of radio service to each of the same.

(c) Omitted.

(d) No license granted for the operation of a broadcasting station shall be for a longer term than three years and no license so granted for any other class of station shall be for a longer term than five years, and any license granted may be revoked as hereinafter provided. Upon the expiration of any license, upon application therefor, a renewal of such license may be granted from time to time for a term of not to exceed three years in the case of broadcasting licenses, and not to exceed five years in the case of other licenses, if the Commission finds that public interest, convenience, and necessity would be served thereby. In order to expedite action on applications for renewal of broadcasting station licenses and in order to avoid needless expense to applicants for such renewals, the Commission shall not require any such applicant to file any information which previously has been furnished to the Commission or which is not directly material to the considerations that affect the granting or denial of such application, but the Commission may require any new or additional facts it deems necessary to make its findings. Pending any hearing and final decision on such an application and the disposition of any petition for rehearing pursuant to section 405 of this title, the Commission shall continue such license in effect. Consistently with the foregoing provisions of this subsection, the Commission may by rule prescribe the period or periods for which licenses shall be granted and renewed for particular classes of stations, but the Commission may not adopt or follow any rule which 
(i) an "initial broadcasting licensee" is a party who holds an initial broadcasting license which has a term of between three and six years.

(ii) a "competing applicant" is a party who is presently challenging the broadcasting licensee in a comparative renewal hearing but who has not successfully challenged the licensee at such a hearing within three years of the present challenge.

(iii) a "preferred applicant" is a party who is presently challenging the broadcasting licensee in a comparative renewal hearing and who has successfully challenged the licensee at such a hearing within three years of the present challenge.

(e) No license granted for the operation of a broadcasting station shall be for a longer term than six years and any license granted may be revoked as hereinafter provided.

(i) When three years remain of any term exceeding three years, an "initial broadcasting licensee" seeking extension of his license term shall submit his record to the Commission for review and, if a "competing applicant" files, for comparison. An extension of such license may be granted for a term of not to exceed three years if the Commission finds that public interest, convenience, and necessity would be served thereby.

(ii) If the Commission finds that public interest, convenience, and necessity would not be so served, it shall, with reasonable detail, so inform the broadcasting licensee of the reasons for the finding. After a broadcasting licensee seeking renewal has completed his term he shall submit his record to the Commission for review and, if a "preferred applicant" files, for comparison. In such review or comparison, if public interest, convenience, and necessity would be served thereby, subject to the limitation of subsection (iii), shall grant an initial broadcast license to any competitor therefor.

(iii) If after a broadcasting licensee has completed his term, a "competing applicant" files and is preferred to the party granted a license in subsection (ii), such license shall be for a term of not more than three years.

(iv) In order to expedite action ... [see present $\S 307(\mathrm{~d})]^{141}$ the Com-

would preclude it, in any case involving a station of a particular class, from granting or renewing a license for a shorter period than that prescribed for stations of such class if, in its judgment, public interest, convenience, or necessity would be served by such action.

(e) No renewal of an existing station license in the broadcast or common carrier services shall be granted more than 30 days prior to the expiration of the original license.

141 This part of present 47 U.S.C. $\S 307$ (d) (1964) should be inserted where the ellipsis is:

In order to expedite action on applications for renewal of broadcasting station licenses and in order to avoid needless expense to applicants for such renewals, the Commission shall not require any such applicant to file any information which previously has been furnished to the Commission or which is not directly material 
mission shall continue such license in effect. Consistently with the foregoing provisions of this subsection, the Commission may by rule prescribe the period or periods for which licenses shall be granted and renewed, but the Commission may not adopt or follow any rule which would preclude it from extending a license for a period less than three years if, in its judgment, public interest, convenience, and necessity would be served by such action.

(f) No license granted for the operation of any other class of station shall be for a longer term than five years and any license granted may be revoked as hereinafter provided. Upon the expiration of any license, upon application therefore, a renewal of such license may be granted from time to time for a term of not to exceed five years, if the Commission finds that the public interest, convenience, and necessity would be served thereby. Consistently with the foregoing provisions of this subsection, the Commission may by rule prescribe the period or periods for which licenses shall be granted and renewed, but the Commission may not follow any rule which would preclude it from granting or renewing a license for a shorter period than that prescribed if, in its judgment, public interest, convenience, and necessity would be served by such action.

(g) same as present section (e)

B. Proposed Amendment to Section $310(b)^{142}$

Following the final sentence of section 310(b) would appear:

Provided that during the final three years of a broadcasting license, no broadcasting licensee can transfer, assign, or dispose of in any manner, his broadcasting license to other than the applicant preferred to such licensee at the last comparative review of his license if such a party exists and if the Commission finds that the public interest, convenience, and necessity would be served thereby.

to the considerations that affect the granting or denial of such application, but the Commission may require any new or additional facts it deems necessary to make its findings. Pending any hearing and final decision on such an application and the disposition of any petition for rehearing pursuant to section 405 of this title, the Commission shall continue such license in effect.

14247 U.S.C. $\$ 310(\mathrm{~b})$ (1964) presently provides:

No construction permit or station license, or any rights thereunder, shall be transferred, assigned, or disposed of in any manner voluntarily or involuntarily, directly or indirectly, or by transfer of control of any corporation holding such permit or license, to any person except upon application to the Commission and upon finding by the Commission that the public interest, convenience, and necessity will be'served thereby. Any such application shall be disposed of as if the proposed transferee or assignee were making application under section 308 of this title for the permit or license in question; but in acting thereon the Commission may not consider vihether the public interest, convenience, and necessity might be served by the transfer assignment, or disposal of the permit or license to a person other than the proposed transferee or assignee. 